\title{
Agricultural development of the Kurgan region in modern conditions
}

\author{
Nina Roznina ${ }^{1, *}$, Maria Karpova ${ }^{1}$, Alla Shulgina ${ }^{2}$, Valentina Borovinskikh ${ }^{2}$, and Alevtina \\ Volkova ${ }^{3}$ \\ ${ }^{1}$ Federal State Budgetary Educational Institution of Higher Education «Kurgan State Agricultural \\ Academy maden after T.S. Maltsev», 641300 Kurgan region, Ketovsky district, Lesnikovo village, \\ Kurgan, Russia \\ ${ }^{2}$ Kurgan State University, 63 Sovetskaya Str., 4, 640000 Kurgan, Russia \\ ${ }^{3}$ Surgut Institute of Economics, Management and Law, 43 Rabochaya Str., 1, 628400 Surgut, Tyumen \\ Region, Khanty-Mansijsk Autonomous District-Yugra, Russia
}

\begin{abstract}
Russia is one of the main producers of agricultural products, which is determined by the large size of its territory, natural conditions, land suitable for the production of agricultural products and other factors. Agriculture is a significant industry, the development of which is focused on both making a profit and ensuring food and national security. The leaders in the production of agricultural products in Russia are: the Krasnodar Krai, Rostov region, Belgorod region, Voronezh region. The Kurgan region is an industrial and agricultural region, for which agriculture is a system-forming branch of the economy, forming the agroindustrial market, food and economic security of the region. The agricultural degree has a significant impact on the standard of living and well-being of the population of the region: size and structure of food, per capita income, consumption of goods, and social standard of living. The article evaluates the dynamics of agricultural production development in the Kurgan region for 2015-2019. The dynamics of crop acreage, animal population, production of products by categories of farms and their implementation in physical terms are studied.
\end{abstract}

\section{Introduction}

The objective of the work is to identify trends in the development of the agricultural economy of the Kurgan region in modern economic conditions. The agro-industrial complex is the leading sector of the economy of the Ural Federal District and the Kurgan Region. The growth of the sustainable development of the agro-industrial complex of the Kurgan region is promoted by the state support of import substitution processes in the domestic food market and the promotion of the export of agricultural products $[1,2]$. The Kurgan region has a great agricultural potential. Availability of land and labor resources available in the region, significant scientific potential, developed transport, engineering and social infrastructure, proximity to major cities (city of Tyumen and city of Yekaterinburg)

\footnotetext{
* Corresponding author: Rozninanina@mail.ru
} 
and the industrial zones of the Urals allow to increase the production of environmentally safe agricultural products in such difficult natural and climatic conditions [3, 4]. The agricultural complex of the Kurgan region is the leading sector of the region's economy. It accounts for about $15 \%$ of the GRP, and up to $38 \%$ of the region's population lives in rural areas. In the agro-industrial complex of the region, there are 229 agricultural farms, 270 food producers, 1186 peasant farm enterprises and 178.7 thousand personal subsidiary plots . The Kurgan region is the most important agricultural region of the UFD. The share of the region in the total volume of agricultural products in Russia as a whole is $0.9 \%$, and the share in the UFD reaches $13.3 \%$. The region specializes in the production of cereals $(1.9 \%$ of the RF), vegetables $(1.4 \%)$, potatoes $(1.0 \%)$, milk $(1.1 \%)$. The share of these types of agricultural products in the corresponding volumes in the UFD is from 11 to $27 \%$.

\section{Materials and methods}

To study the dynamics of agricultural production development in modern conditions, studies were conducted on the example of agricultural organizations in the Kurgan region.

During the processing, studying and analyzing the accumulated materials, various methods of economic analysis were used in the scientific work. The economic and statistical method of research was used to collect and summarize quantitative data and identify patterns of changes in crop acreage, livestock, production and sales of products. The comparison method is used when comparing the indicators of the base year with the reporting year. The method of analysis and synthesis was used in the study of the financial results of agricultural enterprises.

The database for the analysis was the official statistical publications of the Department of the Federal State Statistics Service for the Sverdlovsk region and the Kurgan region https://sverdl.gks.ru/folder/31382?print=1.

\section{Results and discussions}

\subsection{Crop acreage}

The analysis showed that the main performance indicators of agricultural organizations in the Kurgan region decline, which is confirmed by a reduction in the number of agricultural organizations, the average annual number of employees, and the area of agricultural land.

The Kurgan region has agricultural land with an area of 4.5 million hectares, including arable land - 2.3 million hectares, hayfields - 510 thousand hectares, pastures - 745 thousand hectares, deposit s -456 thousand hectares.

The total area of agricultural land in the Kurgan region over the last five-year period decreased by 17.1 thousand hectares and amounted to 1332.6 thousand hectares in 2019 . This negative trend is caused by a decrease in the crop acreage in agrarian economic entities of the region by 62.3 thousand hectares and in the population households by 14.1 thousand hectares. A positive fact is the increase in crop acreage in the region's peasant farm enterprises in 2015-2019 by 56.4 thousand hectares. This trend is explained by the growth in the size of farms in this category, as the average size of the land plot in the farm in 2019 was 387 hectares, which is 85 hectares higher than in 2015. Also, the number of peasant (farm) enterprises in 2015-2019 decreased by 143 units and reached the level of 1043 units in 2019. (Table 1). 
Table 1. Dynamics of the crop acreage by categories of economic entities, thousand hectares.

\begin{tabular}{|c|c|c|c|c|c|c|}
\hline Indicator & $\mathbf{2 0 1 5}$ & $\mathbf{2 0 1 6}$ & $\mathbf{2 0 1 7}$ & $\mathbf{2 0 1 8}$ & $\mathbf{2 0 1 9}$ & $\begin{array}{c}\text { Deviation } \\
\mathbf{2 0 1 9} \text { from } \\
\mathbf{2 0 1 +}(+-)\end{array}$ \\
\hline $\begin{array}{c}\text { In all farm } \\
\text { categories - total }\end{array}$ & 1349.7 & 1362.2 & 1361.4 & 1338.3 & 1332.6 & -17.1 \\
\hline $\begin{array}{c}\text { including in } \\
\text { agricultural } \\
\text { economic entities }\end{array}$ & 856.7 & 840.2 & 817 & 793.9 & 794.4 & -62.3 \\
\hline $\begin{array}{c}\text { in households of } \\
\text { the population }\end{array}$ & 56.1 & 48.9 & 43.8 & 43.2 & 42 & -14.1 \\
\hline $\begin{array}{c}\text { in peasant farm } \\
\text { enterprises and } \\
\text { sole entrepreneurs }\end{array}$ & 436.8 & 473.2 & 500.7 & 501.2 & 493.2 & 56.4 \\
\hline
\end{tabular}

Compiled by the authors using https://sverdl.gks.ru/storage/mediabank/00104_2020.pdf - official statistical publications of the Department of the Federal State Statistics Service for the Sverdlovsk region and the Kurgan region

The crop acreage by types of agricultural crops in the Kurgan region in 2019 are considered in Table 2 .

Table 2. Crop acreage by type of agricultural crops in 2019, thousand hectares.

\begin{tabular}{|c|c|c|c|c|}
\hline Indicator & total & $\begin{array}{c}\text { Agricult } \\
\text { ural } \\
\text { farms }\end{array}$ & $\begin{array}{c}\text { Househol } \\
\text { ds of the } \\
\text { populatio } \\
\text { n }\end{array}$ & $\begin{array}{c}\text { Peasant farm } \\
\text { enterprises } \\
\text { and sole } \\
\text { entrepreneur } \\
\text { s }\end{array}$ \\
\hline Total crop acreage & 1332.6 & 794.4 & 45.0 & 493.2 \\
\hline $\begin{array}{c}\text { including cereals and } \\
\text { legumes }\end{array}$ & 1061.1 & 619.6 & 26.6 & 414.9 \\
\hline potato & 12.9 & 1.9 & 8.5 & 2.5 \\
\hline open ground vegetables & 3.2 & 0.5 & 2.3 & 0.4 \\
\hline
\end{tabular}

Compiled by the authors using https://sverdl.gks.ru/storage/mediabank/00104_2020.pdf - official statistical publications of the Department of the Federal State Statistics Service for the Sverdlovsk region and the Kurgan region

The sown area in 2019 with agricultural crops was 1332.6 thousand hectares, and the largest area of them is occupied by grain and leguminous crops - 1061.1 thousand hectares (79.63\% of the total sown area). The crop acreage of potatoes in 2019 in all economic entities of the region reached the level of 12.9 thousand hectares (which is $0.97 \%$ of the total sown area). The largest area in the Kurgan region is sown with grain and leguminous crops (1061.10 thousand hectares), of which 619.6 thousand hectares are agricultural economic entities, and 414.9 thousand hectares are peasant (farm) enterprices.

\subsection{Animal population}

The livestock industry plays a significant role in the life of society, as it performs a large list of diverse functions, providing the population with food, work, and contributes to the socio-economic development of the region $[5,6]$. The main task of the livestock industry is to ensure the food and economic security of the region and the country as a whole [7]. The volume of production of livestock products is influenced by the number of animals. 
Table 3. Dynamics of the number of animals in the region, thousand heads.

\begin{tabular}{|c|c|c|c|c|c|c|}
\hline Type of animal & $\mathbf{2 0 1 5}$ & $\mathbf{2 0 1 6}$ & $\mathbf{2 0 1 7}$ & $\mathbf{2 0 1 8}$ & $\mathbf{2 0 1 9}$ & $\begin{array}{c}\text { Deviation } \\
\mathbf{2 0 1 9} \text { from } \\
\mathbf{2 0 1 7},(+;)\end{array}$ \\
\hline Cattle & 123.7 & 117.5 & 117.0 & 122.0 & 120.8 & -2.9 \\
\hline Pigs & 94.9 & 87.8 & 81.2 & 77.9 & 77.2 & -17.7 \\
\hline Sheeps and goats & 138.3 & 125.5 & 118.2 & 114.4 & 111.8 & -26.5 \\
\hline
\end{tabular}

Compiled by the authors using https://sverdl.gks.ru/storage/mediabank/00104_2020.pdf - official statistical publications of the Department of the Federal State Statistics Service for the Sverdlovsk region and the Kurgan region

In the analyzed period reduction dynamics of animal populations in the region is marked: cattle by 2.9 thousand heads (in 2019, the number of cattle amounted to 120.8 thousand heads), pigs by 17.7 thousand heads (in 2019, the number of pigs has reached the level of 77.2 thousand heads). The number of sheeps and goats in all categories of farms in the Kurgan region decreased over the analyzed period by 26.5 thousand heads. If in 2015 there were 138.3 thousand heads of sheeps and goats, then in 2019 only 111.8 thousand heads.

The structure of the livestock population by categories of economic entities on average for 2015-2019 is shown in Figure 1.

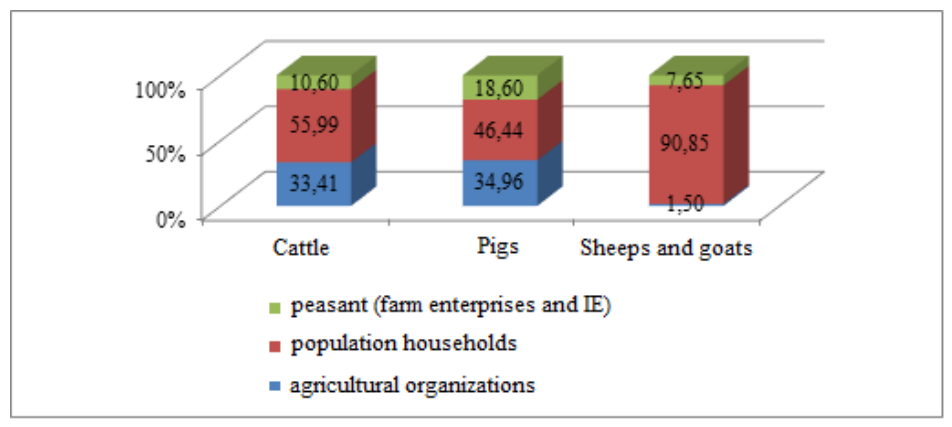

Fig. 1. The structure of the livestock population by categories of economic entities on average for 2015-2019, \%

Analyzing the data of the figure, it should be noted that more than $55 \%$ of cattle are concentrated in the farms of the population of the Kurgan region on average for 2015-2019. The share of cattle in agricultural farms and peasant farm enterprises, respectively, averaged $33.41 \%$ and $10.60 \%$ in $2015-2019$.

In the structure of the pig population, the largest share falls on households of individuals $-46.44 \%$ of the total number of livestock, agricultural organizations are on the second place $-35.96 \%$ and peasant farm enterprises are in the third place $-18.60 \%$.

More than $90 \%$ of the total number of sheeps and goats is in the households of the population.

\subsection{Production and sale of agricultural products}

The Kurgan region is one of the most important agricultural regions of the UFD Region. The share of the Kurgan region in the total cost of agricultural products in Russia was 0.9 $\%$, and the share in the UFD was $13.3 \%$ [8]. Agricultural products of the Kurgan region by categories of farms in value terms are shown in Table 4. 
Table 4. Cost of agricultural products by category of farms, million rubles.

\begin{tabular}{|c|c|c|c|c|c|c|}
\hline Indicator & 2015 & 2016 & 2017 & 2018 & 2019 & $\begin{array}{l}\text { Deviation } \\
2019 \text { from } \\
2015 \text {, (+;-) }\end{array}$ \\
\hline \multicolumn{7}{|c|}{ All economic entities } \\
\hline $\begin{array}{l}\text { Cost of agricultural } \\
\text { products - total }\end{array}$ & 34780.5 & 38094.0 & 38576.7 & 39511.4 & 46410.0 & 11629.5 \\
\hline $\begin{array}{l}\text { including crop } \\
\text { production industries }\end{array}$ & 20305.0 & 21890.1 & 23452.7 & 22248.1 & 29662.7 & 9357.7 \\
\hline $\begin{array}{l}\text { animal husbandry } \\
\text { industries }\end{array}$ & 14475.5 & 16203.9 & 15124.0 & 17263.2 & 16747.3 & 2271.8 \\
\hline \multicolumn{7}{|c|}{ Agricultural farms } \\
\hline $\begin{array}{l}\text { Cost of agricultural } \\
\text { products - total }\end{array}$ & 13700.8 & 14541.1 & 15878.4 & 15131.9 & 19143.4 & 5442.6 \\
\hline $\begin{array}{c}\text { including crop } \\
\text { production industries }\end{array}$ & 10205.4 & 10900.8 & 11739.5 & 10979.6 & 14862.4 & 4657 \\
\hline $\begin{array}{c}\text { Animal husbandry } \\
\text { industries }\end{array}$ & 3495.3 & 3640.3 & 4138.9 & 4152.3 & 4281 & 785.7 \\
\hline \multicolumn{7}{|c|}{ Households of the population } \\
\hline $\begin{array}{l}\text { Cost of agricultural } \\
\text { products - total }\end{array}$ & 15153.9 & 16868.4 & 15777.2 & 17471.8 & 17430.4 & 2276.5 \\
\hline $\begin{array}{c}\text { including crop } \\
\text { production industries }\end{array}$ & 4660.3 & 4819.3 & 5356.7 & 5215.6 & 5903.4 & 1243.1 \\
\hline $\begin{array}{c}\text { Animal husbandry } \\
\text { industries }\end{array}$ & 10493.6 & 12049.1 & 10420.5 & 12256.3 & 11527.0 & 1033.4 \\
\hline \multicolumn{7}{|c|}{ Peasant farm enterprises } \\
\hline $\begin{array}{l}\text { Cost of agricultural } \\
\text { products - total }\end{array}$ & 5925.9 & 6684.4 & 6921.1 & 6907.07 & 9836.1 & 3910.2 \\
\hline $\begin{array}{l}\text { including crop } \\
\text { production industries }\end{array}$ & 5439.3 & 6169.9 & 6356.5 & 6053.1 & 8896.9 & 3457.6 \\
\hline $\begin{array}{c}\text { Animal husbandry } \\
\text { industries }\end{array}$ & 486.6 & 514.5 & 564.6 & 854.6 & 939.2 & 452.6 \\
\hline
\end{tabular}

Compiled by the authors using https://sverdl.gks.ru/storage/mediabank/00104_2020.pdf - official statistical publications of the Department of the Federal State Statistics Service for the Sverdlovsk region and the Kurgan region

The cost estimation of agricultural products of the Kurgan region for 2015-2019 increased by 11629.5 million rubles and amounted to 46410.0 million rubles in 2019 , which is caused by both an increase in crop production and livestock production, respectively, by 9357.7 million rubles and 2271.8 million rubles.

The sale of agricultural products is the final stage of its movement from the producer to the consumer $[9,10]$. The dynamics of the volume of crop production sales by agricultural organizations of the Kurgan region is considered in Table 5.

Table 5. Sales of crop production by agricultural organizations of the Kurgan region, thousand tons.

\begin{tabular}{|c|c|c|c|c|c|c|}
\hline Indicator & $\mathbf{2 0 1 5}$ & $\mathbf{2 0 1 6}$ & $\mathbf{2 0 1 7}$ & $\mathbf{2 0 1 8}$ & $\mathbf{2 0 1 9}$ & $\begin{array}{c}\text { Deviation } \\
\mathbf{2 0 1 9} \text { from } \\
\mathbf{2 0 1 7}(+;-)\end{array}$ \\
\hline Grain & 274.2 & 731.4 & 892.6 & 949.0 & 673.3 & 399.1 \\
\hline Potato & 27.3 & 26.8 & 35.2 & 35.9 & 29.1 & 1.8 \\
\hline Vegetables & 14.5 & 15.0 & 22.4 & 21.6 & 17.0 & 2.5 \\
\hline
\end{tabular}


Compiled by the authors using https://sverdl.gks.ru/storage/mediabank/00104_2020.pdf - official statistical publications of the Department of the Federal State Statistics Service for the Sverdlovsk region and the Kurgan region

In the analyzed period, there was an increase in sales of grain in physical terms by 399.1 thousand tons, potatoes -1.8 thousand tons, vegetables -2.5 thousand tons.

\subsection{Financial results of agricultural organizations}

The main purpose of any business entity functioning is to make a profit - a reliable financial source for the well-being of the business entity and its owners [11-13]. The financial results of agricultural organizations in the Kurgan region have a negative trend (Table 6).

Table 6. Financial results of agricultural organizations

\begin{tabular}{|c|c|c|c|c|c|c|}
\hline Indicator & $\mathbf{2 0 1 5}$ & $\mathbf{2 0 1 6}$ & $\mathbf{2 0 1 7}$ & $\mathbf{2 0 1 8}$ & $\mathbf{2 0 1 9}$ & $\begin{array}{c}\text { Deviation } \\
\mathbf{2 0 1 9} \text { from } \\
\mathbf{2 0 1}(+;-)\end{array}$ \\
\hline $\begin{array}{c}\text { Balanced financial } \\
\text { result, million rubles. }\end{array}$ & 901.1 & 380.8 & 283.5 & 249.7 & 375.1 & -526 \\
\hline $\begin{array}{c}\text { Share of unprofitable } \\
\text { organizations, \% }\end{array}$ & 17.4 & 20 & 28.2 & 32.6 & 16.7 & -0.7 \\
\hline $\begin{array}{c}\text { Amount of losses, } \\
\text { million rubles. }\end{array}$ & 44.4 & 123.6 & 279.6 & 158.7 & 114.8 & 70.4 \\
\hline $\begin{array}{c}\text { Share of profit-making } \\
\text { organizations, \% }\end{array}$ & 82.6 & 80 & 71.8 & 67.4 & 83.3 & 0.7 \\
\hline $\begin{array}{c}\text { Amount of profit, } \\
\text { million rubles. }\end{array}$ & 945.5 & 504.4 & 563.1 & 408.4 & 489.9 & -455.6 \\
\hline
\end{tabular}

Compiled by the authors using https://sverdl.gks.ru/storage/mediabank/00104_2020.pdf - official statistical publications of the Department of the Federal State Statistics Service for the Sverdlovsk region and the Kurgan region

In 2015-2019, the dynamics of a decrease was noted in the balanced financial result by 526 million rubles, the amount of profit by 455.6 million rubles. The amount of losses of agricultural farms in the Kurgan region in 2019 amounted to 114.8 million rubles, which is 70.4 million rubles higher than in 2015. Agricultural farms received the maximum amount of profit in 2015 - 945.5 million rubles, and the loss in 2017 - 279.6 million rubles.

\section{Conclusions}

Based on the conducted research, it can be concluded that the development of the agricultural economy of the Kurgan region in modern conditions has an ambiguous trend. Thus, in 2017-2019, there was an increase in the cost of agricultural products, both in general and by industry. The negative point is the decrease in crop acreage, the number of pigs, sheeps and goats, grain production in volume terms, and the availability of agricultural machinery in the agricultural sector.

\section{References}

1. M.V. Karpova, N.V. Roznina, Scientific and innovative technologies as a factor of sustainable development of the agro-industrial complex, 385 (2020) 
2. G.Ya. Ostaev, D.V. Kondratiev, O.V. Kotlyachkov, E.A. Konina, S.N. Suetin, L.A. Istomina, Amazonia Investiga, 8, 135 (2019)

3. E.G. Mukhina, Agrarian Bulletin of the Urals, 11(129), 63 (2014)

4. R.B. Shestakov, E.I. Lovchikova, Region Economy, 15, 908 (2019)

5. E.S. Sokolova, N.V. Roznina, M.V. Karpova, Topical Issues of Modern Economy, 4, 381 (2019)

6. N.I. Ivanov, T.V. Shevchenko, V.S. Gorbunov, RUDN JOURNAL, 14, 520 (2019)

7. V.L. Somov, Statistics Issues, 26, 47 (2019)

8. T.N. Medvedeva, I.A. Artamonova, I.N. Baturina, E.A. Farvazova, N.V. Roznina, E.G. Mukhina, IOP Conference Series: Materials Science and Engineering, 341, 012010 (2019)

9. E.G. Vorobyova, I.G. Kildyushkina, Region Studies, 27, 246 (2019)

10. M.S. Oborin, A.P. Andreev, V.P. Cherdantsev, Vestnik of the Kazan State Agrarian University, 14, 128 (2019)

11. I.V. Deryugina, Journal Vostok (Oriens), 1, 129 (2013)

12. V.V. Maslova, V.S. Chekalin, M.V. Avdeev, Herald of the Russian Academy of Sciences, 89, 1024 (2019)

13. D.Yu. Samygin, N.G. Baryshnikov, L.A. Mizyurkina, Economy of region, 15, 865 (2019) 